Indo. J. Chem. Res., 2017, 5(1), 47-52

\title{
MODIFIKASI KATALIS CAO UNTUK PRODUKSI BIODIESEL DARI MINYAK BEKAS
}

\section{Modification of $\mathrm{CaO}$ Catalyst to Produce Biodiesel From Waste Cooking Oil}

\author{
St. Annisa Gani Rachim*, Indah Raya,Muhammad Zakir \\ ${ }^{I}$ Department of Chemistry, Faculty of Mathematics and Natural Sciences, Hasanuddin University \\ Jl. Perintis Kemerdekaan Km. 10, Tamalanrea, Makassar, 90245 - Indonesia \\ "Corresponding author, e-mail: st.annisagr@gmail.com
}

Received: June 2017 Published: July 2017

\begin{abstract}
Research about modification of $\mathrm{CaO}$ catalyst to produce biodiesel has done. This research aims to know the effectiveness of $\mathrm{CaO}-\mathrm{ZnCl}_{2}$ belong to ASTM D6751 to get a yield biodiesel. Modification of the $\mathrm{CaO}$ with $\mathrm{ZnCl}_{2}$ was conducted by impregnation method using methanol and n-hexane. For synthesis biodiesel, methanol is used as solvent and Waste Cooking Oil (WCO) as raw material. Ratio molar of WCO and methanol is $12: 1 \mathrm{with} 3 \% \mathrm{CaO}-$ $\mathrm{ZnCl}_{2}$ added. This reaction is carried out at a temperature of $65^{\circ} \mathrm{C}$. The biodiesel is characterized by Fourier Transform Infrared (FT-IR) to determine the presence of ester groups formed. The yield percentage of biodiesel produced is $77.94 \%$. The characterization of biodiesel properties consist of acid number is $73.38 \mathrm{mg} \mathrm{KOH} / \mathrm{g}$, density is 0.9038 and water content is $0.0053 \%$.
\end{abstract}

Keywords: Biodiesel, waste cooking oil, $\mathrm{CaO}, \mathrm{ZnCl}_{2}$, modification

\section{PENDAHULUAN}

Kebutuhan bahan bakar premium (fosil) di Indonesia terus mengalami peningkatan dengan nilai rata-rata 10 persen per tahun.Volume kendaraan dan industri yang terus berkembang secara tidak langsung meningkatkan konsumsi bahan bakar fosil sehingga untuk memenuhi kebutuhan tersebut sekitar 60-70 persen dari konsumsi bahan bakar fosil diperoleh dari hasil impor. Hal ini mengakibatkan ketergantungan terhadap hasil impor sehingga menurunkan devisa Negara. Untuk mengatasi masalah tersebut maka diperlukan upaya dalam mengurangi ketergantungan terhadap penggunaan bahan bakar fosil.Salah satu upaya tersebut adalah pengembangan energi baru terbarukan seperti Bahan Bakar Nabati (BBN).Biodiesel merupakan salah satu BBN yang ramah lingkungan dan dapat diperbarui (Jupesta, 2010). Tahun 2016, pemerintah telah menetapkan penggunaan B20 (campuran $20 \%$ biodiesel dan $80 \%$ solar) pada industri biodiesel dan diprediksikan akan naik menjadi B30 pada tahun 2030.

Bahan baku dalam pembuatan biodiesel yang telah banyak digunakan berasal dari bahan alam seperti tumbuhan dan biji-bijian. Namun, penggunaan bahan alam sebagai bahan baku pembuatan biodiesel masih kurang efisien jika dibandingkan dengan penggunaan limbah minyak bekas (minyak jelantah) karena membutuhkan lahan yang luas. Minyak jelantah sangat mudah diperoleh, baik dari industri rumah tangga maupun dari restoran. Minyak jelantah merupakan limbah yang akan bersifat karsinogenik jika digunakan secara berulang. Minyak jelantah yang digunakan pada proses pembuatan biodiesel ini adalah minyak jelantah yang telah dimurnikan terlebih dahulu guna menurunkan kandungan asam lemak bebas (FFA) hingga $\leq 0,05 \%$. Tingginya kandungan FFA dari bahan baku yang digunakan dapat menyebabkan terjadinya reaksi saponifikasi (sabun) dengan katalis yang digunakan (Maneerung dkk., 2016).

Katalis berfungsi mempercepat laju reaksi dan menurunkan energi aktifasi sehingga proses produksi biodiesel dapat berlangsung singkat. Katalis yang umum digunakan adalah katalis homogen seperti $\mathrm{NaOH}$ dan $\mathrm{H}_{2} \mathrm{SO}_{4}$ karena waktu reaksinya yang singkat pada suhu rendah. Akan tetapi, katalis homogen memiliki kekurangan karena dapat bereaksi dengan FFA yang akan menyebabkan sulitnya pemisahan dan 


\section{St. Annisa G. Rachim dkk. / Indo. J. Chem. Res., 2017, 5(1), 47-52}

pembentukan produk biodiesel. Oleh karena itu, katalis heterogen dianggap lebih efektif dan efisien dalam pembuatan biodiesel karena disamping harganya yang murah, mudah diperoleh dan dapat digunakan kembali (Komintarachat dan Chuepeng, 2009; Roschat dkk., 2016; Sirimsomboonchai dkk., 2015).

Katalis $\mathrm{CaO}$ merupakan katalis heterogen terbaik dengan aktivitas katalitik dan kebasaan yang cukup tinggi, memiliki kelarutan yang rendah dalam metanol serta penggunaannya yang lebih mudah karena tidak membutuhkan air pencucian yang berlebihan.Katalis $\mathrm{CaO}$ dapat diperoleh dari hasil kalsinasi $\mathrm{CaCO}_{3}$ yang berasal dari limbah cangkang kepiting karena berdasarkan pola difraksi diindikasikan bahwa cangkang kepiting memiliki kandungan $\mathrm{CaCO}_{3}$ yang tinggi dan setelah dikalsinasi pada suhu $1000^{\circ} \mathrm{C}$ diperoleh $\mathrm{CaO}$ dengan kemurnian yang tinggi.Namun dalam penggunaannya, katalis $\mathrm{CaO}$ mudah bereaksi dengan $\mathrm{CO}_{2}$ dan $\mathrm{H}_{2} \mathrm{O}$ di udara sehingga menyebabkan aktivitas katalitiknya menjadi kurang efektif. Inilah alasan diperlukannya penambahan zat aktif dengan mengkombinasikan katalis $\mathrm{CaO}$ dengan menggunakan katalis logam lain (Kesic dkk., 2016).

Penelitian mengenai kombinasi katalis $\mathrm{CaO}$ dengan katalis logam lain telah banyak dilakukan, seperti $\mathrm{CaO} / \mathrm{ZnO}, \mathrm{CaO} / \mathrm{Al}_{2} \mathrm{O}_{3}, \mathrm{CaO} / \mathrm{Li}, \mathrm{CaO} / \mathrm{K}$ dan $\mathrm{CaO} / \mathrm{KF}$ karena dapat meningkatkan aktivitas katalitik, memperbesar luas permukaan dan dapat mengurangi pembentukan sabun dalam produksi biodiesel. Hasil konversi yang dihasilkan pun sangat tinggi yakni sebesar 90\% (Kesic dkk., 2016 dan Setiawati dan Edward, 2012). Menurut Jin, dkk (2014), katalis asam lewis baik digunakan dalam reaksi esterifikasi maupun transesterifikasi. Katalis asam lewis seperti $\mathrm{ZnCl}_{2}$ dapat memberikan hasil yang signifikan setelah waktu 6 jam dengan suhu $100-110^{\circ} \mathrm{C}$ (Khan dan Fatima, 2016). Pada penelitian ini telah dilakukan modifikasi katalis $\mathrm{CaO}$ dengan mengkombinasikan katalis $\mathrm{CaO}$ dengan katalis asam lewis $\mathrm{ZnCl}_{2}$ untuk mengetahui efektivitas dari penggunaan $\mathrm{ZnCl}_{2}$ terhadap katalis $\mathrm{CaO}$ beserta yield biodiesel.

\section{METODOLOGI}

\section{Bahan}

Bahan yang digunakan dalam penelitian ini adalah Minyak jelantah, abu sekam padi, $\mathrm{CaO}$, $\mathrm{ZnCl}_{2}$ metanol p.a, etanol pa, $\mathrm{KOH}$ E-Merck,
$\mathrm{NaOH}$ E-Merck, indikator fenopthalein, asam oksalat, akuades, tissue, kertas saring biasa, kertas saring Whatman no. 1, kertas saring Whatman no. 42, aluminium foil, kertas label, batu didih, vaselin, n-heksana teknis, natrium sulfat anhidrat.

\section{Alat}

Alat yang digunakan dalam penelitian ini adalah furnace, oven, X-ray diffraction (XRD), Xray Fluorescence (XRF), Fourier-transform infrared spectroscopy (FTIR), corong pisah, satu set alat refluks, hotplate, termometer, neraca analitik Ohaus, neraca Mettler Toledo PL602-S, statif dan klem, buret, pipet volume, pipet skala 10 $\mathrm{mL}$, cawan porselin, cawan petri, desikator, lumping besi, ayakan 100 mesh, spatula, batang pengaduk, gelas piala, gelas ukur, erlenmeyer, bar magnetic stirrer, penangas air, pompa vakum, penyaring Buchner, piknometer $10 \mathrm{~mL}$, viscometer Ostwald, bulp, corong Buchner, adaptor.

\section{Prosedur Kerja \\ Pemurnian Minyak Jelantah}

Proses pemurnian dilakukan melalui proses netralisasi. Sebanyak $2 \mathrm{~L}$ minyak jelantah ditambahkan $2 \mathrm{~L}$ air dan dipanaskan hingga volume air tersisa setengahnya.Kemudian minyak tersebut disaring dengan kertas saring Whatman untuk memisahkan minyak dari kotoran yang mengendap. Selanjutnya, minyak yang telah disaring ini dipanaskan hingga mencapai suhu $35^{\circ} \mathrm{C}$ dan ditambahkan larutan $\mathrm{NaOH} 6 \%$ dengan komposisi $4 \mathrm{~mL}$ setiap $100 \mathrm{~mL}$ minyak. Campuran minyak jelantah dan $\mathrm{NaOH} 6 \%$ diaduk selama 10 menit pada suhu $40^{\circ} \mathrm{C}$ dan selanjutnya didinginkan kemudian disaring untuk memisahkan minyak jelantah dengan kotoran.

\section{Preparasi Katalis}

Katalis $\mathrm{CaO}$ diperoleh melalui proses kalsinasi cangkang kepiting pada suhu $900^{\circ} \mathrm{C}$ selama 3 jam. Katalis $\mathrm{CaO}$ yang diperoleh selanjutnya dimodifikasi melalui metode impregnasi menggunakan $\mathrm{ZnCl}_{2}$. $\mathrm{CaO}$ dan $\mathrm{ZnCl}_{2}$ (perbandingan 1:1) dilarutkan ke dalam metanol dan distirer selama 3 jam. Larutan ini kemudian disaring dengan pompa vakum sambil dicuci menggunakan $\mathrm{n}$-heksana dan akuades hingga filtratnya berwarna bening. Residu yang dihasilkan kemudian dioven selama 2 jam dan selanjutnya difurnace selama 1,5 jam pada suhu $500^{\circ} \mathrm{C}$. 
St. Annisa G. Rachim dkk. / Indo. J. Chem. Res., 2017, 5(1), 47-52

\section{Sintesis Biodiesel}

30 g minyak jelantah dimasukkan dalam labu leher tiga dan dipanaskan hingga suhu $70^{\circ} \mathrm{C}$. Setelah itu, dimasukkan metanol yang sebelumnya telah dicampurkan dengan katalis $\mathrm{CaO}-\mathrm{ZnCl}_{2}(3 \%$ dari berat minyak) dengan perbandingan molar 12:1 dengan minyak jelantah dan direfluks selama 4 jam pada suhu $65^{\circ} \mathrm{C}$. Campuran ini kemudian dimasukkan dalam corong pisah dan didiamkan selama satu hari.Pada campuran terbentuk tiga fasa dimana pada fasa atas dan tengah berupa metil ester dan gliserol sedangkan fasa bawah berupa katalis.Fasa bawah kemudian dipisahkan dari campuran dan fasa atas diekstraksi dengan akuades.Pada campuran ini terbentuk dua fasa, fasa atas berupa metil ester dan fasa bawah berupa gliserol yang bercampur dengan metanol.Fasa atas selanjutnya ditambahkan dengan $\mathrm{Na}_{2} \mathrm{SO}_{4}$ anhidrat dan didiamkan selama satu malam. Metil ester yang diperoleh kemudian disaring dan dipanaskan pada suhu $90^{\circ} \mathrm{C}$ selama satu jam untuk memperoleh metil ester yang murni (biodiesel).

\section{Uji Karakteristik Sifat Fisik Biodiesel Analisis Densitas Biodiesel}

Penentuan densitas biodiesel dilakukan pada suhu $40^{\circ} \mathrm{C}$ dengan menggunakan alat piknometer.Cara kerjanya yaitu : piknometer kosong yang telah dibersihkan dan dikeringkan ditimbang mengunakan neraca analitik. Akuades yang sudah dipanaskan pada suhu $40^{\circ} \mathrm{C}$ dimasukkan dalam piknometer sampai penuh dan suhunya dicatat. Bagian dinding luar piknometer dikeringkan dan ditimbang lalu bobotnya dicatat. Selanjutnya, akuades diganti dengan biodiesel yang telah dipanaskan pada suhu $40-43^{\circ} \mathrm{C}$ dan ditimbang. Hasil penimbangan dicatat dalam satuan gram. Prosedur ini dilakukan sebanyak dua kali.

\section{Analisis Kadar Air}

Penentuan kadar air dilakukan dengan memanaskan contoh dalam oven pada suhu 105$110^{\circ} \mathrm{C}$. Pertama, wadah tahan panas dioven pada suhu $105-110^{\circ} \mathrm{C}$ selama 30 menit kemudian ditempatkan pada desikator. Setelah dingin, wadah ditimbang sehingga diperoleh berat wadah kosong. Selanjutnya, ke dalam wadah ditambahkan 0,5 gram minyak jelantahkemudian dioven pada suhu $105-110^{\circ} \mathrm{C}$ selama satu jam. Wadah yang berisi sampel didinginkan dalam desikator kemudian ditimbang sampai berat konstan. Pekerjaan ini diulang sebanyak dua kali (Sudarmadji, dkk., 1989).

\section{Analisis Asam Lemak Bebas}

Biodiesel sebanyak 0,2 g dimasukkan dalam labu Erlenmeyer $100 \mathrm{~mL}$, ditambahkan $5 \mathrm{~mL}$ alkohol netral 95\% kemudian dipanaskan dalam waterbath hingga terbentuk larutan homogen. Setelah didinginkan kemudian dititrasi dengan $\mathrm{KOH}$ 0,1N menggunakan indikator Phenolphtalein. Dihitung kadar asam lemak bebasnya.

\section{HASIL DAN PEMBAHASAN}

\section{Karakterisasi Katalis $\mathbf{C a O}-\mathbf{Z n C l}_{\mathbf{2}}$}

Preparasi katalis $\mathrm{CaO}$ dilakukan melalui metode impregnasi menggunakan asam lewis $\mathrm{ZnCl}_{2}$ sebagai pengemban. Penambahan pengemban menghasilkan kadar metil ester yang lebih tinggi dibandingkan penggunaan katalis tanpa menggunakan pengemban. Hal ini disebabkan tingginya aktivitas katalitik yang dimiliki oleh katalis $\mathrm{CaO}$ dengan pengemban (Enggawati dan Ediati, 2013).

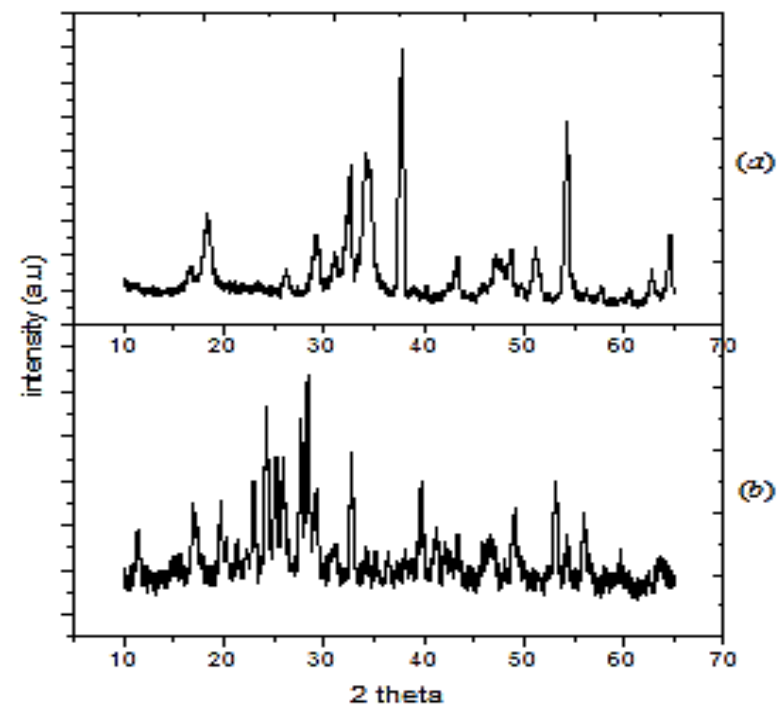

Gambar 1. Pola Difraksi hasil XRD (a) $\mathrm{CaO}$ dan (b) $\mathrm{CaO}-\mathrm{ZnCl}_{2}$

Pelarut yang digunakan adalah metanol dan $\mathrm{n}$ heksana dimana metanol berfungsi menarik zat pengganggu yang bersifat polar sedangkan nheksana berfungsi untuk menarik pengotor yang bersifat non polar. Metode ini digunakan untuk meningkatkan aktivitas katalitik dan memperbesar luas permukaan dari $\mathrm{CaO}$. Hasil impregnasi ini 
St. Annisa G. Rachim dkk. / Indo. J. Chem. Res., 2017, 5(1), 47-52

selanjutnya diuji dengan XRD seperti pada Gambar 1.

Pola difraksi dari hasil kalsinasi cangkang kepiting pada Gambar 1(a) memiliki kesesuaian dengan pola difraksi $\mathrm{CaO}$ murni pada Joint Committee on Powder Diffraction Standards (JCPDS. CaO hasil kalsinasi memiliki nilai $2 \theta=$ $32,5^{\circ} ; 37,72^{\circ} ; 54,25^{\circ} ; 64,51^{\circ}$ dan $67,74^{\circ}$, sedangkan $2 \theta$ pada JCPDS adalah $2 \theta=32,59^{\circ}$; $37,75^{\circ} ; 54,25^{\circ} ; 64,54^{\circ}$ dan $67,76^{\circ}$. Adanya penambahan $\mathrm{ZnCl}_{2}$ pada $\mathrm{CaO}$ mengakibatkan terjadinya pergeseran $2 \theta$ menjadi 31,$01 ; 36,15^{\circ}$, $51,95^{\circ}$ dan $64^{\circ}$. Nilai ini cukup signifikan dengan nilai $2 \theta$ pada $\mathrm{CaO}$ murni sehingga dapat dikatakan bahwa $\mathrm{ZnCl}_{2}$ dapat digunakan dalam telah terimpregnasi ke dalam $\mathrm{CaO}$.

\section{Pemurnian Minyak Jelantah}

Pada proses sintesis biodiesel, minyak jelantah yang digunakan dimurnikan melalui proses netralisasi menggunakan larutan $\mathrm{NaOH} 6 \%$ yang bertujuan untuk menurunkan kadar asam lemak bebas (FFA) yang terkandung di dalam minyak jelantah. Larutan $\mathrm{NaOH}$ akan bereaksi dengan FFA membentuk sabun. Pembentukan sabun juga dipengaruhi oleh tingginya nilai bilangan asam, dimana semakin tinggi nilai bilangan asam maka semakin tinggi pula kandungan FFA yang terdapat pada bahan baku. Hal ini akan menyebabkan sulitnya proses pemisahan pada produk yang dihasilkan (Nurhasnawati, 2015)..

Berdasarkan hasil perhitungan asam lemak bebas dan bilangan asam terhadap minyak jelantah yang digunakan sebagai bahan dasar biodiesel diperoleh nilai FFA sebesar $89 \%$ dan bilangan asam sebesar 139,3 (mgKOH/g). Hasil ini menunjukan bahwa bilangan asam yang diperoleh pada penelitian ini melebihi standar ASTM yang ditetapkan yakni sebesar $1,9 \mathrm{mgKOH} / \mathrm{g}$. Tingginya bilangan asam pada minyak jelantah yang digunakan menyebabkan terjadinya saponifikasi dan pembentukan emulsi yang mengganggu jalannya reaksi transesterifikasi. Proses pemurnian akhir pada produk biodiesel yang dihasilkan sulit untuk dipisahkan. Identifikasi lebih lanjut mengenai minyak jelantah yang telah dinetralisasi ditunjukkan pada Gambar 2.

Gambar 2 menunjukkan adanya gugus ester yang menandakan terbentuknya trigliserida pada proses netralisasi minyak jelantah yang ditandai dengan adanya gugus karbonil pada bilangan gelombang $1745,58 \mathrm{~cm}^{-1}$ dan gugus $-\mathrm{C}-\mathrm{O}$ pada $1745,58 \mathrm{~cm}^{-1}$. Selain itu, senyawa $\mathrm{H}_{2} \mathrm{O}$ juga terbentuk yang ditandai dengan munculnya peak lemah pada bilangan gelombang $3471,87 \mathrm{~cm}^{-1}$. Munculnya $\mathrm{H}_{2} \mathrm{O}$ ini mengakibatkan tingginya kandungan FFA sehingga menyebabkan terbentuknya saponifikasi pada produk akhir.

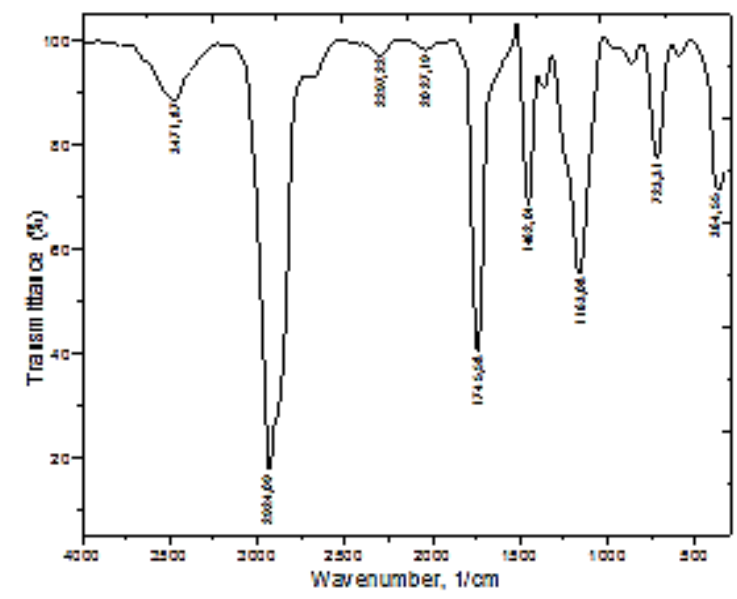

Gambar 2. Spektrum IR untuk minyak jelantah hasil netralisasi

Tabel 1.Spektrum IR untuk minyak jelantah hasil netralisasi

\begin{tabular}{cc}
\hline $\begin{array}{c}\text { Bilangan gelombang } \\
\left(\mathbf{c m}^{-\mathbf{1}}\right)\end{array}$ & Hasil analisis \\
\hline 723,31 & $\mathrm{C}-\mathrm{H}$ stretching \\
1163,08 & $\mathrm{C}-\mathrm{O}-\mathrm{C}$ stretching dari \\
gugus fungsi ester \\
1745 & $\mathrm{C}=\mathrm{O}$ stretching vibration \\
2924,09 & $-\mathrm{CH}_{2}$ - stretching \\
& vibration, asimetri \\
3471,87 & $\mathrm{O}-\mathrm{H}$, ikatan hidrogen \\
\hline
\end{tabular}

\section{Sintesis Biodiesel}

Sintesis biodiesel diperoleh melalui reaksi transesterifikasi antara minyak jelantah dan metanol dengan penambahan katalis $\mathrm{CaO}-\mathrm{ZnCl}_{2}$ $3 \%$ dari berat minyak. Perbandingan molar antara minyak jelantah dengan metanol yang digunakan adalah sebesar 1:12. Penelitian mengenai perbandingan molar ini telah dilakukan oleh Musa, 2016 dengan hasil konversi yang tinggi, yaitu sebesar $\geq 77,94 \%$. Suhu yang digunakan adalah $65^{\circ} \mathrm{C}$ yang merupakan suhu optimum dari pelarut yang digunakan dalam reaksi transesterifikasi ini (Muthu dan Viruthagiri, 2015). 


\section{St. Annisa G. Rachim dkk. / Indo. J. Chem. Res., 2017, 5(1), 47-52}

\section{Identifikasi Gugus Fungsi}

Produk biodiesel yang dihasilkan pada penelitian ini dianalisis menggunakan FTIR untuk mengidentifikasi adanya gugus fungsi ester (biodiesel).

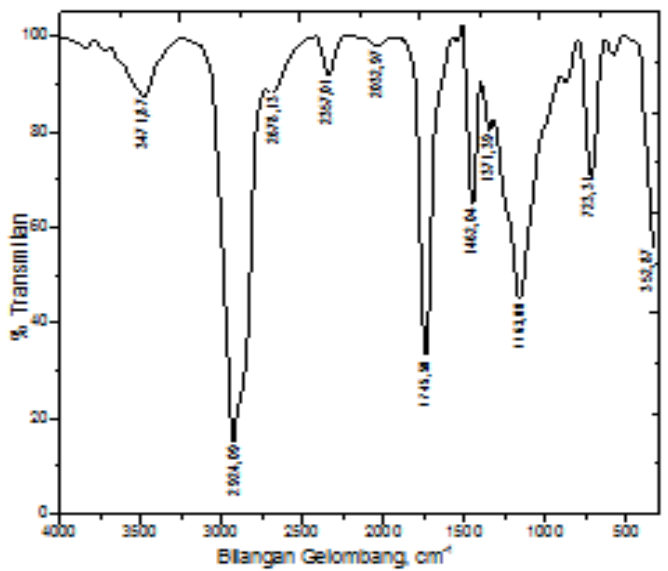

Gambar 3. Spektrum FT-IR Biodiesel

Gambar 3 menunjukkan spektra IR untuk bahan baku biodiesel pada spektrum serapan pada bilangan gelombang 1745,58 $\mathrm{cm}^{-1}$ yang menunjukkan adanya gugus karbonil $(\mathrm{C}=\mathrm{O})$ dari senyawa ester, $1163,03 \mathrm{~cm}^{-1}$ menunjukkan adanya ikatan $\mathrm{C}-\mathrm{O}$. Bilangan gelombang pada 1654,92 $\mathrm{cm}^{-1}$ menunjukkan adanya ikatan $\mathrm{C}=\mathrm{C}$, sementara pada $3003,17 \mathrm{~cm}^{-1}$ menunjukkan adanya ikatan $\mathrm{C}$ $\mathrm{H}$ alkena.

\section{Karakterisasi Biodiesel}

Hasil uji karaterisasi biodiesel diperoleh dan dibandingkan dengan hasil uji ASTM D6751 nampak pada Tabel 2.

Tabel 2. Hasil uji karakterisasi biodiesel berdasarkan hasil penelitian dan ASTM D6751

\begin{tabular}{ccc}
\hline Jenis uji & Biodiesel & $\begin{array}{c}\text { ASTM } \\
\text { D6751 }\end{array}$ \\
\hline Kadar Air $(\%)$ & 0,0053 & $\begin{array}{c}\text { Maks. 0,05 } \\
\text { Densitas 40 }\end{array} 0^{\circ} \mathrm{C}$ \\
$\left(\mathrm{kg} / \mathrm{m}^{3}\right)$ & 0,9038 & $0,86-9$ \\
$\begin{array}{c}\text { Bilangan Asam } \\
(\mathrm{mg} \mathrm{KOH} / \mathrm{g})\end{array}$ & 73,38 & Maks. 0,8 \\
\hline
\end{tabular}

Tabel 2 menunjukkan karakterisasi dari biodiesel yang dihasilkan pada penelitian ini belum sepenuhnya sesuai dengan standar ASTM yang ditetapkan. Hal ini disebabkan masih tingginya kandungan bilangan asam yang terdapat pada bahan baku yang digunakan meskipun telah dinetralisasi, dimana tingginya bilangan asam akan menyebakan terbentuknya saponifikasi yang mengganggu jalannya reaksi transesterifikasi. Saponifikasi yang terbentuk juga akan mempengaruhi kekentalan produk sehingga akan menyebabkan tingginya nilai densitas pada biodiesel yang dihasilkan. Meskipun demikian, yield biodiesel yang dihasilkan cukup tinggi yaitu sebesar $77,94 \%$.

\section{KESIMPULAN}

Berdasarkan pada hasil yang diperoleh maka dapat disimpulkan bahwa :

1. Terbentuk gugus ester pada hasil spektrum FTIR yang ditandai dengan adanya gugus karbonil pada panjang gelombang 1745,58 $\mathrm{cm}^{-1}$ dan gugus C-O $1163,03 \mathrm{~cm}^{-1}$ adalah ciri khas bahwa biodiesel telah terbentuk

2. Yield biodiesel yang dihasilkan sebesar $77,94 \%$.

3. Kadar air biodiesel 0,0053\%; densitas pada suhu $40^{\circ} \mathrm{C}$ adalah $0,9038 \mathrm{~kg} / \mathrm{m}^{3}$ dan bilangan asam adalah 73,38 mg-KOH/g.

\section{DAFTAR PUSTAKA}

Enggawati, E.R. dan Ediati, R., 2013, Pemanfaatan Kulit Telur Ayam dan Abu Layang Batubara sebagai Katalis Heterogen untuk Reaksi Transesterifikasi Minyak Nyamplung (Calophyllum Inophyllum Linn), J. Sains dan Seni Pomits, 2(1):2337-3520.

Jin, B., Duan, P., Xu, Y., Wang, B., Wang, F., Zhang, L., 2014, Lewis acid-catalyzed in situ Transesterification/Esterificationof Microalgae in Supercritical Ethanol, Bio Tech, 162: 341-349.

Kesic, Z., Lukic, I., Zdujic, M., Mojovic, L. and Skala, D., 2016, Calcium Oxide Based Catalysts For Biodiesel Production : A Review, Chem Ing Chem Eng Q., 22 (4) : 391408.

Khan, A.M. dan Fatima, N., 2016, Biodiesel Synthesis via Metal Oxides and Metal Chlorides Catalysis from Marine Alga Melanothamnus afaqhusainii, Chinese $J$. ofChem Eng, 24 :388-393.

Komintarachat, C. dan Chuepeng, S. 2009, Solid Catalyst for Biodiesel Production from Waste Cooking Oils, Ing Eng Chem Res, 48 : 93509353. 
St. Annisa G. Rachim dkk. / Indo. J. Chem. Res., 2017, 5(1), 47-52

Jupesta, J., 2010, Impact of The Introduction of Biofuel in The Transportation Sector in Indonesia, Sustainability, 2:1831-1848.

Maneerung, T., Kawi, S., Dai, Y. dan Wang, C.H., 2016, Sustainable Biodiesel Production via Trasesterification of Waste Cooking Oil bu Using $\mathrm{CaO}$ Catalyst Prepared From Chicken Manure, Energy Conv and Man., 123 : 487497.

Nurhasnawati, H., 2015, Penetapan Kadar Asam Lemak Bebas dan Bilangan Peroksida pada Minyak Goreng yang digunakan Pedaganng Gorengan diJalan A.W Sjahranie Samarinda, J. Ilmiah Manuntung, 1(1):25-30

Roschat, W., Siritanon, T., Kaewpuang, T., Yoosuk, B. dan Promarak, V., 2016, Economical and Green Biodiesel Production Process Using River Snail Shells-Derived Heterogeneous Catalyst and Co-Solvent Method, Bio Tech 209, 343-350.
Setiawati, E dan Edwar, F., 2012, Teknologi Pengolahan Biodiesel dari Minyak Goreng Bekas dengan Teknik Mikrofiltrasi dan Transesterifikasi sebagai Alternatif Bahan Bakar Mesin Diesel, Jurnal Riset Industri, 6 (2) : 117-127.

Sirisomboonchai, S., Abuduwayiti, M., Guan, G., Samart, C., Abliz, S., Hao, X., Kusakabe, K., Abudula, A., 2015, Biodiesel Production from Waste Cooking Oil Using Calcined Scallop Shell as Catalyst, Energy Conversion and Management, 95 : 242-247. 